Article

\title{
Climate Preferences for Tourism: Perceptions Regarding Ideal and Unfavourable Conditions for Hiking in Spain
}

\author{
Emilio Martínez-Ibarra ${ }^{1, *(1)}$, María Belén Gómez-Martín ${ }^{2}$ (), Xosé Anton Armesto-López ${ }^{2}$ \\ and Rubén Pardo-Martínez ${ }^{1}$ \\ 1 Departamento de Análisis Geográfico Regional y Geografía Física, Facultad de Filosofía y Letras, Campus \\ Universitario de Cartuja, Universidad de Granada, 18071 Granada, Spain; rubenpardo@ugr.es \\ 2 Departament de Geografia, Universitat de Barcelona, Carrer de Montalegre, 6-8, 08001 Barcelona, Spain; \\ bgomez@ub.edu (M.B.G.-M.); armesto@ub.es (X.A.A.-L.) \\ * Correspondence: emibarra@ugr.es
}

Received: 2 October 2019; Accepted: 23 October 2019; Published: 25 October 2019

\begin{abstract}
Physical activity is an increasingly frequent part of our leisure time. Within this context, hiking is a popular form of tourism which has a positive impact on the quality of life. In spite of the importance of climate conditions for this recreational activity, relatively little research has been done on hiking from the perspective of climate and tourism. With this in mind in this paper we make the first detailed extensive assessment of climate preferences for the practice of hiking tourism in Spain. To this end a review of the theoretical/methodological body of literature on tourism climatology was conducted together with a survey aimed at evaluating the stated climate preferences of hiking tourists. The results are offered within the framework of international research on climate preferences for a range of tourism activities. The comparative analysis of these results with regard to those obtained in previous research highlights various similarities but also certain factors specific to hiking in Spain. Overall, the climate preferences of hiking tourists are similar to those of other segments of the tourism market in terms of the aesthetic and physical aspects of the climate, although they also have certain specific preferences as regards thermal aspects, especially regarding the optimal daily thermal conditions for hiking. The results obtained are useful for assessing the suitability of the climate for the practice of hiking tourism in Spain and for promoting proper management and planning of this leisure activity in tourist destinations, including the development of climate calendars detailing the most suitable times of the year for hiking at these destinations. These issues will be addressed in future research studies.
\end{abstract}

Keywords: hiking; tourism climatology; preferences; Spain

\section{Introduction}

We need leisure time to combat the stress of work and our general daily lives and this can be spent doing a range of activities, including relaxation, socializing and physical activity [1].

Physical activity is a basic component of a healthy lifestyle, which increases life expectancy, improves the immune function and has numerous other benefits for physical and mental health $[2,3]$. When physical exercise is conducted in natural outdoor environments, it helps reduce depression increasing one's sensation of satisfaction, enjoyment and wellbeing as well as making the person concerned more likely to continue doing this activity $[4,5]$.

Physical activity in the open air can be affected by factors that are beyond human control [6], such as seasonal variations in the climate $[7,8]$, the length of the day [9] and climatic variables such as temperature $[10,11]$, the intensity of the wind $[10,11]$ and rainfall $[9,10]$. Phenomena such as extreme 
heat, strong wind, intense rain and low temperatures tend to dissuade people from engaging in physical activity [1,11-15].

The increasing popularity of outdoor activities in recent years has produced a number of important economic impacts affecting a range of agents and activities [16]. One example is that more and more people choose to spend their holidays doing different physical activities [17] such as hiking, which is widely recognized as one of the most important attractions for tourists visiting natural areas. In fact, in protected mountain areas hiking is now the most popular recreational activity [18-21].

The promotion of hiking as one of the activities on offer at a particular tourist destination is an interesting way of promoting experiences in contact with nature [22], and also encourages people to engage in an active form of tourism that benefits their health and wellbeing $[23,24]$. Support for and implementation of hiking tourism products that encourage sustainable mobility and transport and their promotion at the destination can all be important elements in the fight against global warming. In fact, the reasonable development of hiking as an activity in certain mountain destinations hitherto linked with winter sports is being proposed as a means of adapting them to the expected rise in temperatures and the fall in the amount of precipitation, which will make it more difficult or impossible to continue with snow-related activities such as skiing. For example, in the case of Spain, a country considered a hotspot in terms of the effects of climate change [25], the introduction of hiking tourism products in mountain regions is considered one of the best options for the socioeconomic survival of these areas [26-28].

In the field of tourism climatology so far little research has been done on the hiking-climate binomial at international level. Most of the studies offer a general view, focusing on the climate preferences for tourism in mountain areas, without specifying whether their results were applicable to hiking [29-33]. One explicit reference to hiking appeared in a report by the Canadian Federal Ministry of the Environment in the 1970s, in which they proposed "physiognomic" types of weather for carrying out a range of tourism activities, including what they referred to as tourist walks [34,35]. A more recent study looked at the influence of atmospheric conditions on mountain hiking in Taiwan [36], while in Spain specific results were obtained by researchers studying hiking on the island of Mallorca [16].

Our aim (research question) in this paper is to continue this research so as to reach conclusions regarding the most favourable and unfavourable conditions for hiking in Spain from a climate-tourism perspective. The object of this research is therefore to discover whether there are any similarities or differences with respect to other studies researching the same and different segments of tourism demand in Spain and in other countries and regions. To this end our work will be based on and will build on the findings made by Martínez-Ibarra and Pardo-Martínez in 2017 [28].

\section{Background and Data}

In spite of the important economic importance of tourism, which accounts for $10 \%$ of worldwide GDP [37], and of the relationship between atmospheric and climatic conditions and tourism [38], tourism climatology is a relatively recent branch of knowledge and research [39]. Its theoretical and methodological development began in the early 1990s with the pioneering work by Besancenot [40] and de Freitas [41]. The theoretical and methodological framework for the research in this paper is based on these early studies and on those conducted subsequently by de Freitas [42], Martínez-Ibarra and Gómez-Martín [43] and Gómez-Martín et al. [44]. To this end, in this paper we will bed looking at three specific facets of the weather: aesthetic, physical and thermal. These facets affect four fundamental requirements of tourists today: safety, enjoyment, comfort and health. The effects of all other aspects of climate must also be taken into account [41].

The aesthetic quality of the outdoor atmosphere is affected by the level of sunlight, the cloudiness, the length of the day, the visibility and the air quality [41-43]. The physical facet is related with certain climate elements which either come in material form (precipitation in solid or liquid form, particles in suspension) or are capable of moving matter (wind) [41-43]. The thermal facet is linked to thermal comfort and is affected by the temperature, the atmospheric humidity, the wind and the level 
of sunlight [41-43]. The different parameters within these three facets influence the tourist's sensation of safety, enjoyment, comfort and health [43].

Furthermore, within the climate-tourism combination, the usual atmospheric conditions, their variability (which now includes climate change) and possible extreme events all affect the tourism product in that they influence the attractiveness of the destination and the resources available there. The influence of the weather is manifested during the tourists' stay [45] and is a common source of dissatisfaction [46,47] or satisfaction [47-49] for them, as it can affect their access to and use of these tourism resources [50-54]. The tourists' safety can also be affected by the atmospheric conditions in the event of extreme climate events taking place [55-58]. The atmospheric context is also important in the phase prior to the tourist actually making the journey, in that climate plays a fundamental role in the travel decision-making process [59-66]. The atmospheric conditions are also important during the trip itself [67] and even later on once the tourist has returned home [68,69].

These different facets of climate not only affect the demand for tourism services but also the supply. In the medium to long term they can condition the type of services on offer, especially in destinations which are dependent on the climate resource. In the short-term they can also affect the availability of these resources to the tourist (e.g., insufficient snow for skiers or too much wind for windsurfers), so damaging the profitability of the businesses concerned.

Lastly, it is important to make clear that the relationship between climate and tourism is not purely one-directional and instead operates both ways in that tourism also influences atmospheric conditions at both a local and a global scale [35,43] (Figure 1).

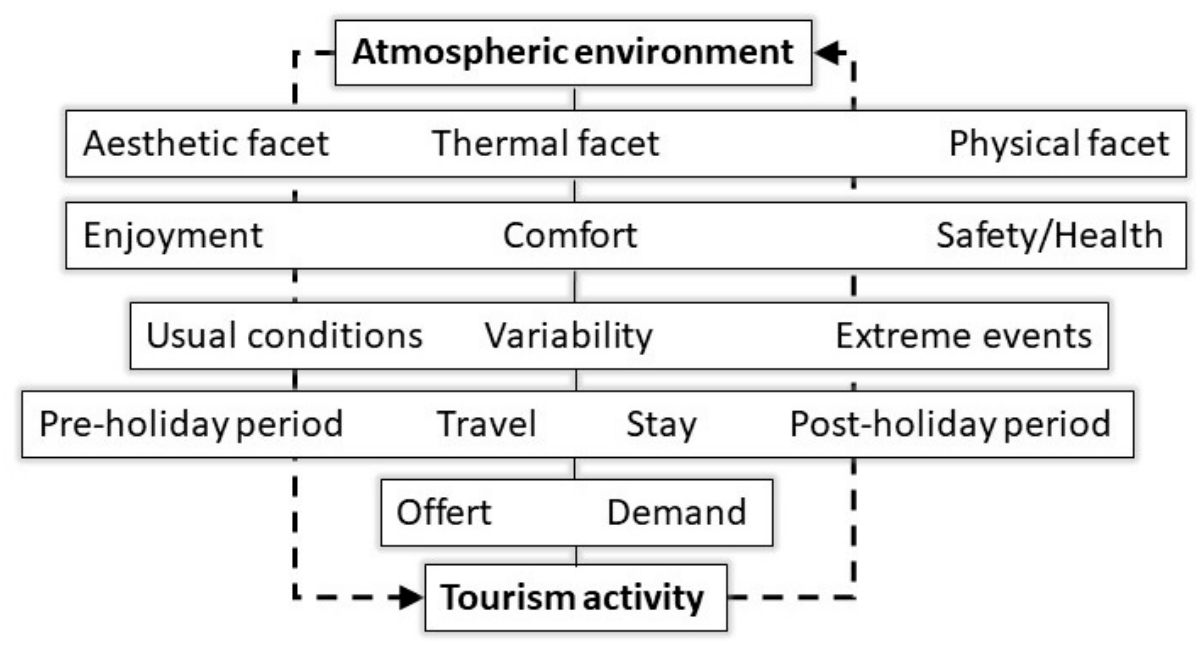

Figure 1. Climate-tourism relationship. Source: [40-44]. Created during this research.

This close relationship between climate and tourism means that one of the main challenges facing researchers in the field of tourism climatology is to estimate what the ideal climate would be for a range of tourism-related activities [40,42]. In this paper we will be focusing on one of these activities, hiking, and the most suitable climate for hiking in Spain. In addition to the reasons given in the introduction section regarding the increasing importance of physical activity and of hiking tourism, Spain was chosen as a suitable research area for this study because detailed, extensive analyses of this question have yet to be made in this country.

There are three main procedures for assessing the climate preferences of tourists [42]. The first is expert opinion based either on the researcher's own experience or, failing this, on the information he/she receives from specialists in the field. The drawback with this procedure is that it has not been empirically tested. The studies by Mieczkowski and Besancenot et al. [70,71] or more recently by Yu et al. [72] are examples that fall within this category. The second procedure involves establishing links between tourism demand and climate conditions (revealed preferences). On this issue, it is important to bear in mind, as de Freitas argued, that "behaviour can be used as a measure of human sensitivity and 
satisfaction" [42]. The papers by Martínez-Ibarra [73] and Gómez-Martín and Martínez-Ibarra [53] can be classified within this category. The third procedure involves conducting surveys to find out people's climate preferences for particular kinds of tourism (stated preferences). Numerous studies have followed this procedure [31-34,42,74-79]. In this research we used this last technique, carrying out an "ex situ" survey, i.e., the surveys were not conducted "in situ" in places where people go hiking, but via the Internet, as in the papers by Dubois et al. [31,33]. This enables large amounts of information to be gathered without the need to travel.

A total of 326 questionnaires in Spanish were completed between 2016 and 2018. This process took a long time because we wanted to obtain the largest number of valid questionnaires, i.e., those in which all the questions were answered. The sampling was non-random or non-probabilistic. It was based on questionnaires filled out online by voluntary, altruistic respondents.

The questions drafted for the questionnaire took into account both the climate-tourism matrix $[28,43]$ and the previous research papers that applied this assessment technique (survey) to identify climate- tourism preferences [31-33,42,74-78,80]. As a result, the following variables were analysed: cloudiness, atmospheric visibility, precipitation, wind speed and temperature. The questions were grouped by climatic facets, following the sequence and response options shown in results and discussion section. Additional information was reported in the response options for the wind variable. Specifically the visual effects associated with each level of force, according to the Beaufort scale.

The objective was to assess the ideal conditions and the acceptance limits (unfavourable conditions) for each variable mentioned earlier. It is important to establish where people's limits lie in terms, for example, of what they consider to be an acceptable amount of rain. This is because classifying a day as favourable or suitable for performing a particular tourism activity should not involve a sum of the different variables, given that the tourists' expectations could be dashed if the extremes in just one climate element were surpassed (e.g., too hot or too windy) even if the other weather conditions were apparently ideal [75]. Those responding to the questionnaire were also asked about how important certain climate parameters are for them, such as the type of precipitation. All results are shown as percentage response.

As regards the characteristics of the sample group, almost all respondents declared that they were aged between 18 and 65 years old (97\%). The most frequent age groups being between 30 and 50 years old $(57.3 \%)$ and between 50 and $65(24.8 \%)$. The distribution in terms of sex was $37.3 \%$ women and $62.7 \%$ men. Practically all the participants declared that they had at least one year's experience of hiking $(91.6 \%)$, while $76.1 \%$ were frequent hikers (at least once a month), and the vast majority (76.6\%) had higher education studies. Although the sample group was relatively small (in terms of the number of people surveyed), the fact that almost all those questioned were experienced hikers makes their answers more significant, so reducing possible problems with a small sample group of 326 people (Table 1).

Table 1. Technical specifications of the survey.

\begin{tabular}{cc}
\hline Components & Characteristics \\
\hline Type of survey & "Ex situ" \\
Medium & Internet \\
Period & 2016 and 2018 \\
Valid questionnaires & 326 \\
Sample type & Non-random \\
Higher Education & $76.6 \%$ \\
Hiking experience $\geq 1$ year & $91.6 \%$ \\
\hline
\end{tabular}

\section{Results and Discussion}

When analysing the aesthetic facet of the weather, the variables we focused on were cloudiness and atmospheric visibility. As regards the ideal state of the sky for hiking, respondents were given the following answer options: clear, slightly cloudy, cloudy and very cloudy. Almost all the respondents opted for skies with no or little cloud (Table 2), so much so that when added together the "clear" 
and "slightly cloudy" options totalled $90.5 \%$ (Table 2). These results were similar to those obtained for various other types of tourism activities at different times of the year. For example: for summer tourism in general [34,70,81]; for sun and beach tourism [42,73,79]; city tourism [42,82]; or mountain tourism [42] (Table 3). When asked about the most unfavourable conditions for hiking, in line with the previous results, most of those interviewed opted for highly overcast skies (the "very cloudy" option was chosen by $61.9 \%$ ) (Table 2). These results can be explained by the fact that sunlight provides between $15-40 \%$ of our sensation of enjoyment [83-85]. De Freitas [40] found that cloudiness levels of over $40 \%$ made the beach $30 \%$ less attractive for users.

Table 2. Synthesis of the results by climatic facets.

\begin{tabular}{|c|c|c|c|}
\hline Facets & Question & Answer Options & $\begin{array}{c}\text { Results (Percentage } \\
\text { Response) }\end{array}$ \\
\hline \multirow[t]{12}{*}{ Aesthetic } & Ideal Cloudiness & Clear & 48.4 \\
\hline & & Slightly Cloudy & 42.1 \\
\hline & & Cloudy & 8.5 \\
\hline & & Very Cloudy & 0.9 \\
\hline & Unfavourable Cloudiness & Clear & 2.6 \\
\hline & & Slightly Cloudy & 8.5 \\
\hline & & Cloudy & 27.0 \\
\hline & & Very Cloudy & 61.9 \\
\hline & Ideal atmospheric visibility & Lack of any mist or fog & 76.2 \\
\hline & & Mist or haze & 14.3 \\
\hline & & Light fog & 4.8 \\
\hline & & Moderate fog & 4.7 \\
\hline \multirow[t]{24}{*}{ Physical } & Ideal Precipitation & No rain & 94.6 \\
\hline & & Rain & 5.4 \\
\hline & Unfavourable Precipitation & $0.1-1 \mathrm{~mm}$ & 5.4 \\
\hline & & $1-5 \mathrm{~mm}$ & 18.3 \\
\hline & & $5-10 \mathrm{~mm}$ & 42.6 \\
\hline & & $10-15 \mathrm{~mm}$ & 33.6 \\
\hline & Ideal wind & F0 $\left(0-1 \mathrm{~km} \cdot \mathrm{h}^{-1}\right)$ & 25.8 \\
\hline & & F1 $\left(2-5 \mathrm{~km} \cdot \mathrm{h}^{-1}\right)$ & 21.5 \\
\hline & & F2 $\left(6-11 \mathrm{~km} \cdot \mathrm{h}^{-1}\right)$ & 22.2 \\
\hline & & F3 $\left(12-19 \mathrm{~km} \cdot \mathrm{h}^{-1}\right)$ & 12.7 \\
\hline & & F4 $\left(20-28 \mathrm{~km} \cdot \mathrm{h}^{-1}\right)$ & 7.3 \\
\hline & & F5 $\left(29-38 \mathrm{~km} \cdot \mathrm{h}^{-1}\right)$ & 7.5 \\
\hline & & F6 (39-49 km.h h $\left.^{-1}\right)$ & 2.3 \\
\hline & & F7 (50-61 km.h $\left.\mathrm{h}^{-1}\right)$ & 0.0 \\
\hline & & F8 $\left(62-74 \mathrm{~km} / \mathrm{h}^{-1}\right)$ & 0.6 \\
\hline & Unfavourable wind & $\mathrm{F} 1\left(2-5 \mathrm{~km} \cdot \mathrm{h}^{-1}\right)$ & 0.7 \\
\hline & & F2 $\left(6-11 \mathrm{~km} \cdot \mathrm{h}^{-1}\right)$ & 1.4 \\
\hline & & F3 $\left(12-19 \mathrm{~km} \cdot \mathrm{h}^{-1}\right)$ & 4.1 \\
\hline & & F4 $\left(20-28 \mathrm{~km} \cdot \mathrm{h}^{-1}\right)$ & 7.7 \\
\hline & & F5 $\left(29-38 \mathrm{~km} \cdot \mathrm{h}^{-1}\right)$ & 19.6 \\
\hline & & F6 (39-49 km.h $\left.{ }^{-1}\right)$ & 28.6 \\
\hline & & F7 $\left(50-61 \mathrm{~km} \cdot \mathrm{h}^{-1}\right)$ & 27.8 \\
\hline & & F8 $\left(62-74 \mathrm{~km} / \mathrm{h}^{-1}\right)$ & 8.2 \\
\hline & & $\mathrm{F} 9\left(>75 \mathrm{~km} / \mathrm{h}^{-1}\right)$ & 1.8 \\
\hline \multirow[t]{11}{*}{ Thermal } & Ideal maximum temperature & $5-10{ }^{\circ} \mathrm{C}$ & 1.7 \\
\hline & & $10-15^{\circ} \mathrm{C}$ & 21.6 \\
\hline & & $15-20^{\circ} \mathrm{C}$ & 53.8 \\
\hline & & $20-25^{\circ} \mathrm{C}$ & 20.3 \\
\hline & & $25-30{ }^{\circ} \mathrm{C}$ & 2.2 \\
\hline & & $>30^{\circ} \mathrm{C}$ & 0.4 \\
\hline & Unfavourable maximum temperature & $15-20^{\circ} \mathrm{C}$ & 1.4 \\
\hline & & $20-25^{\circ} \mathrm{C}$ & 4.5 \\
\hline & & $25-30^{\circ} \mathrm{C}$ & 32.7 \\
\hline & & $30-35{ }^{\circ} \mathrm{C}$ & 45.0 \\
\hline & & $35-40{ }^{\circ} \mathrm{C}$ & 16.5 \\
\hline
\end{tabular}


Table 3. Optimum weather conditions for different daily tourism activities.

\begin{tabular}{|c|c|c|c|c|c|c|c|c|}
\hline \multirow[t]{2}{*}{ Region } & \multirow[t]{2}{*}{$\begin{array}{l}\text { Demand } \\
\text { Segment }\end{array}$} & \multicolumn{6}{|c|}{ Atmospheric Variables } & \multirow[t]{2}{*}{ Source } \\
\hline & & $\mathrm{T}\left({ }^{\circ} \mathrm{C}\right)$ & $\mathrm{WT}\left({ }^{\circ} \mathrm{C}\right)$ & $\mathrm{P}(\mathrm{mm})$ & $\mathrm{W}\left(\mathrm{Km} \cdot \mathrm{h}^{-1}\right)$ & I (hour or \%) & $\mathrm{N}(\%)$ & \\
\hline France & $\begin{array}{l}\text { General } \\
\text { (summer) }\end{array}$ & {$[25,33]$} & - & 0 & $<28.8$ & $\geq 9$ & $\leq 25$ & [70] \\
\hline Brazil & General & $\geq 28$ & - & $\leq 1$ & $\leq 10.8$ & $\geq 9$ & $\leq 40$ & [86] \\
\hline Temperate climates & $\begin{array}{l}\text { General } \\
\text { (summer) }\end{array}$ & {$[25,31]$} & - & 0 & $<28.8$ & $\geq 9$ & $\leq 25$ & [40] \\
\hline Catalonia (Spain) & $\begin{array}{l}\text { General } \\
\text { (summer) }\end{array}$ & {$[22,28]$} & - & 0 & $<28.8$ & $\geq 11$ & $\leq 25$ & [34] \\
\hline Cuba & General & {$[22,31]$} & - & 0 & $<28.8$ & $\geq 7$ & $\leq 38$ & {$[88]$} \\
\hline Brazil & $\begin{array}{l}\text { General } \\
\text { (summer) }\end{array}$ & {$[26,30]$} & - & 0 & {$[16,20]$} & - & 0 & {$[81]$} \\
\hline $\begin{array}{l}\text { United Kingdom (Wales) and } \\
\text { Mediterranean region (Turkey and Malta) }\end{array}$ & Sun and beach & $\begin{array}{c}{[32.5,34.5]} \\
\text { Skin temperature }\end{array}$ & {$[22,26]$} & - & $\leq 14.4$ & - & - & [74] \\
\hline Coast of Alicante (Spain) & Sun and beach & {$[28,31]$} & $\geq 25$ & 0 & $<28.8$ & $\geq 75 \%$ & - & [35] \\
\hline Canada, New Zealand and Sweden & Sun and beach & $26.8[25,28]$ & - & - & {$[1,9]$} & - & $\leq 25$ & [89] \\
\hline Canada and Caribbean & Sun and beach & {$[25,30]$ and $[27,30]$} & - & 0 and $<15^{\prime}$ & $\leq$ Light breeze & - & - & {$[90]$} \\
\hline Greece & Sun and beach & $30[28,32]$ & & 0 & $\leq$ Light breeze & & $\leq 25$ & [79] \\
\hline Canada, New Zealand and Sweden & Urban & $22.5[19,26]$ & - & - & {$[1,9]$} & - & $\leq 25$ & [89] \\
\hline Canada & Snow & {$[-20,5]$} & & $\begin{array}{c}\text { No liquid } \\
\text { precipitation }\end{array}$ & $<23.4$ & & $\begin{array}{l}>0.8 \mathrm{Km} \\
\text { visibility }\end{array}$ & [91] \\
\hline Canada, New Zealand and Sweden & $\begin{array}{l}\text { Mountain } \\
\text { (general) }\end{array}$ & $20.5[15,26]$ & - & - & {$[1,9]$} & - & $\leq 25$ & [89] \\
\hline Taiwan & $\begin{array}{l}\text { Mountain } \\
\text { (hiking) }\end{array}$ & $>25$ & - & - & - & - & - & [36] \\
\hline Germany & $\begin{array}{l}\text { Mountain } \\
\text { (general) }\end{array}$ & {$[21,25]$} & - & - & - & - & - & [92] \\
\hline Spain & Hiking & {$[15,19]$} & - & 0 & $<28$ & - & $\begin{array}{l}\leq \text { few partly } \\
\text { cloudy ones }\end{array}$ & {$[28]$} \\
\hline Mallorca (Spain) & $\begin{array}{l}\text { Mountain } \\
\text { (hiking) }\end{array}$ & $13[10,15]$ & - & - & - & - & 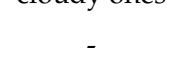 & [16] \\
\hline Spain & Hiking & {$[15,19]$} & - & 0 & $\leq 19$ & - & $\begin{array}{l}\leq \text { few partly } \\
\text { cloudy ones }\end{array}$ & $\begin{array}{l}\text { Present } \\
\text { study }\end{array}$ \\
\hline
\end{tabular}

Source: Created during this research. 
Atmospheric visibility is an important problem for certain tourist activities [52], including hiking [93]. As de Freitas indicated when discussing tourism activities in general, the level of visibility affects the quality of the experience in that it influences our enjoyment of the tourism destination and its particular qualities [42]. The possible answer options regarding visibility preferences for hiking were established according to the thresholds proposed by Llorente-Martínez [94]. The following answer options were offered: lack of mist and fog; some mist and haze (visibility between 1 and $10 \mathrm{~km}$ ); light fog (visibility between 500 and $1000 \mathrm{~m}$ ); moderate fog (visibility between 50 and $500 \mathrm{~m}$ ); and thick fog (visibility of less than $50 \mathrm{~m}$ ). Most of the respondents (76.2\%) defined the ideal conditions for hiking as no mist and fog (Table 2). This shows, as might be expected, that people tend to prefer conditions in which there is good visibility, as pointed out in the reports published by the Canadian Federal Ministry of the Environment in the 1970s [34].

When analysing the physical facet, the variables were daily precipitation and maximum wind speed. As regards precipitation, respondents were also asked about the quantity, intensity and type. Almost all agreed that the ideal situation for hiking was a day with no rain at all $(94.6 \%)$. Various authors consider the $0 \mathrm{~mm}$ daily precipitation threshold as ideal $[35,40,41,73,95-97]$ for tourism in general and for sun and beach tourism in particular (Table 3). In the event of some rain falling, the daily maximum limit tolerated by most respondents to our survey was $5 \mathrm{~mm} /$ day $(76.2 \%)$; this maximum limit coincides with that established for sun and beach tourism by Martínez-lbarra in 2008 [96] (Table 4). As regards the maximum intensity of precipitation considered acceptable for hiking, most respondents would accept up to moderate intensity rainfall (46.7\%). When asked about the type of precipitation, most respondents considered the amount of precipitation more important than the form in which it occurs (53.2\%). As regards the type of precipitation, most of those interviewed preferred snow, then rain and finally hail ( $45 \%)$; or rain, snow and finally hail $(44.5 \%)$. In previous research, precipitation was found to be the most important variable for tourism in France [31] and also for mountain tourism in the Alpine area of Bavaria [32].

When assessing the daily maximum wind speed, respondents were offered several closed options according to the Beaufort scale, as used in previous research by Gómez-Martín [96]. Their answers indicate that the ideal situation is a day with very light winds (Table 2); most of the respondents $(82.2 \%)$ chose the 0 to 3 windspeed group, in other words between the wind thresholds of 0 to $19 \mathrm{~km} / \mathrm{h}$ (maximum speed for a light breeze). These results are similar to those obtained for other tourism segments and other geographical areas [43,97]. Those interviewed set the maximum windspeed threshold for hiking at $50 \mathrm{~km} / \mathrm{h}(62.1 \%)$. This threshold is similar to that assimilated in other research papers $[76,82,98]$ for other kinds of tourism (Table 4 ). 
Table 4. Unfavourable weather conditions for different kinds of tourism activities at a daily scale.

\begin{tabular}{|c|c|c|c|c|c|c|c|c|}
\hline \multirow[t]{2}{*}{ Region } & \multirow[t]{2}{*}{$\begin{array}{l}\text { Demand } \\
\text { Segment }\end{array}$} & \multicolumn{6}{|c|}{ Atmospheric Variables } & \multirow[t]{2}{*}{ Source } \\
\hline & & $\mathrm{T}\left({ }^{\circ} \mathrm{C}\right)$ & $\mathrm{WT}\left({ }^{\circ} \mathrm{C}\right)$ & $\mathrm{P}(\mathrm{mm})$ & $\mathrm{W}\left(\mathrm{Km} \cdot \mathrm{h}^{-1}\right)$ & I (hour or \%) & $\mathrm{N}(\%)$ & \\
\hline France & $\begin{array}{l}\text { General } \\
\text { (summer) }\end{array}$ & $<16 /-$ & - & $\geq 1$ & $\geq 43.2$ & $<3$ & $>75$ & {$[70]$} \\
\hline Brazil & General & $<22 /-$ & - & $>10$ & $>25.2$ & $<3$ & $>80$ & [86] \\
\hline Temperate climates & $\begin{array}{l}\text { General } \\
\text { (summer) }\end{array}$ & $<16 />33$ & - & $\geq 1$ & $\geq 43.2$ & $<3$ & $>75$ & [40] \\
\hline Catalonia (Spain) & $\begin{array}{l}\text { General } \\
\text { (summer) }\end{array}$ & $<16 />33$ & - & $\geq 1 \mathrm{~h}$ & $\geq 43.2$ & $<5$ & $>75$ & [34] \\
\hline France & General & $<14 />32$ & - & - & - & - & - & [31] \\
\hline $\begin{array}{l}\text { Austria, Germany, Netherlands and } \\
\text { Switzerland }\end{array}$ & General & $<22 />37$ & - & - & - & - & - & {$[76]$} \\
\hline Brazil & General & $<21 />35$ & - & - & $\leq 10 />25$ & - & $\geq$ Cloudy & [81] \\
\hline $\begin{array}{l}\text { United Kingdom (Wales) and } \\
\text { Mediterranean region (Turkey and Malta) }\end{array}$ & Sun and beach & 它 & & & $>21.6$ & - & 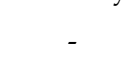 & {$[74]$} \\
\hline Coast of Alicante (Spain) & Sun and beach & $<18 />35$ & - & $\geq 5$ & $>36$ & $<35 \%$ & - & [96] \\
\hline Canada and Caribbean & Sun and beach & $\begin{array}{c}<21 />33 \text { and }<23 /> \\
34\end{array}$ & - & $>15^{\prime}$ and $<30^{\prime}$ & $\begin{array}{l}\geq \text { Strong } \\
\text { winds }\end{array}$ & - & $\geq 75$ & {$[90]$} \\
\hline France & $\begin{array}{l}\text { Coast and sun } \\
\text { and beach }\end{array}$ & $-/ \geq 33$ and $-1 \geq 34$ & & & & & & [33] \\
\hline Greece & Sun and beach & $<22 />39$ & & $\geq 2.5 \mathrm{~h}$. & $\begin{array}{l}\geq \text { Strong } \\
\text { winds }\end{array}$ & & $\geq 75$ & [79] \\
\hline China & Urban & $<0 / \geq 34$ & - & $\geq 2 \mathrm{~h}$ & $\geq 41$ & - & Any & [82] \\
\hline France & Mountain & $-\mid \geq 30$ & - & - & - & - & - & [33] \\
\hline- & Hiking & $<3.07 /-$ & - & - & - & - & - & [99] \\
\hline Taiwan & $\begin{array}{l}\text { Mountain } \\
\text { (hiking) }\end{array}$ & $-/ \geq 32$ & - & - & - & - & - & {$[36]$} \\
\hline Germany & $\begin{array}{l}\text { Mountain } \\
\text { (general) }\end{array}$ & $\leq 15 / \geq 30$ & - & - & - & - & - & [92] \\
\hline Spain & Hiking & $<-3 / \geq 31$ & - & $>10$ & $>50$ & - & $\begin{array}{l}=\text { Mostly } \\
\text { cloudy }\end{array}$ & {$[28]$} \\
\hline Mallorca (Spain) & $\begin{array}{l}\text { Mountain } \\
\text { (hiking) }\end{array}$ & $<7 / \geq 26$ & - & - & - & - & - & [16] \\
\hline Spain & Hiking & $<-5 / \geq 35$ & - & $\geq 5$ & $>50$ & - & $\begin{array}{l}=\text { Mostly } \\
\text { cloudy }\end{array}$ & $\begin{array}{l}\text { Present } \\
\text { study }\end{array}$ \\
\hline
\end{tabular}


As regards the thermal facet, according to most of those questioned, the ideal range for maximum daily temperatures for hiking is $15-20^{\circ} \mathrm{C}$. These results are close to those obtained for mountain tourism by Scott [89], who established an ideal value of $20.5^{\circ} \mathrm{C}$ (Table 3) and slightly higher than the range established by Lera et al. [16] for hiking in Mallorca (Spain) of $10-15^{\circ} \mathrm{C}$ (Table 3). When asked about the maximum acceptable temperatures for hiking, most respondents chose the $25-30^{\circ} \mathrm{C}(32.7 \%)$ and $30-35{ }^{\circ} \mathrm{C}(45 \%)$ ranges, bearing in mind that maximum temperatures of over $25^{\circ} \mathrm{C}$ are normally considered hot days [100]. These temperatures were close to those estimated for mountain tourism by Dubois et al. in $2009\left(30^{\circ} \mathrm{C}\right)$ [31] and Jänicke et al. [32], but were notably higher than those established for hiking in Mallorca where the maximum limit was set at $25-26{ }^{\circ} \mathrm{C}$ [17] (Table 4). As regards the low temperature limit, most respondents opted for the 0 to $-5{ }^{\circ} \mathrm{C}$ range $(73.4 \%)$. This minimum threshold is similar to that considered for city tourism in China by Gou in $2015\left(0^{\circ} \mathrm{C}\right)$ [82]; or for hiking in France by $\mathrm{Li}$ in $2008\left(<3.07^{\circ} \mathrm{C}\right)$ [99]. However, it is significantly lower than that estimated for hiking in Mallorca (Spain) [16], which set a minimum limit of $<7^{\circ} \mathrm{C}$. In any case the considerations of Steiger et al. [92] must also be taken into account. These authors indicate that tourists who perform physical-activity-related leisure activities in mountain areas are more tolerant of low temperatures. In fact, in the report by the Canadian Federal Ministry of the Environment very low temperatures were proposed for the practice of skiing or the use of snowmobiles with humidex (an index combining temperature, humidity and dew point) values of -14.4 for skiing and -21.1 for snowmobiles [34].

Finally, when asked about the best season for going hiking, most respondents chose the spring (53.7\%), followed at quite some distance by the autumn (29.4\%). Winter and summer were minority preferences with $6.4 \%$ and $6.2 \%$, respectively. Spring is also the season selected by most foreign tourists for visiting mountain areas of Spain [26].

\section{Conclusions}

The aim of this study was to offer interesting insights into stated climate preferences for the practice of hiking as a tourism activity in Spain. It should be noted that according to the international literature review made by Verbos et al. [101] of weather studies in outdoor recreation and nature-based tourism, little research of this kind had been done on hiking. To this end we studied a population sample, most of whom had higher education studies, went hiking frequently and had at least one year's hiking experience. Surveys were carried out "ex situ" and respondents were asked not only about the ideal climate conditions for hiking but also about what they considered as unfavourable conditions, specifying acceptable maximum and minimum thresholds.

As regards the aesthetic aspect of the weather conditions, it is important to make clear that as with other tourism activities, the respondents stated their preferences for days with no or light cloud. In addition, and as a novel aspect of our research, they also stated their preferences for atmospheric states with no fog and with good visibility, variables that were not included in the literature review by Verbos et al. [101]. As mentioned earlier, sunlight plays an important role in tourists' sensation of enjoyment.

In terms of the physical facet, as happens with other tourism activities, those who go hiking in Spain prefer days with no precipitation. As previously indicated by other authors [40], the appearance of rain can by itself cause the tourist to think that all the weather conditions are unfavourable for doing the activity in question. As regards the other physical facet assessed, wind, respondents expressed a preference for situations with no or only light wind (i.e., with wind speeds of less than $20 \mathrm{~km} / \mathrm{h}$ ). An interesting finding was that hikers in Spain appear to be more tolerant of the wind than other types of tourist (in that they accept maximum speeds of up to $50 \mathrm{~km} / \mathrm{h}$ ). However, it is important to remember that wind speeds in excess of this threshold may affect tourists' enjoyment of whatever activity they are doing and, on some occasions, even their safety.

As regards the thermal facet, the first finding of note is that respondents indicated more demanding preferences in terms of thermal comfort than other kinds of tourists, particularly when compared with sun and beach tourism. The preferred temperature for the practice of hiking in Spain is close 
to the "physiological zero" of $16.9^{\circ} \mathrm{C}$ defined by Besancenot et al., below which we feel cold [70]. At the other end of the scale, hikers seemed to be more flexible than other tourists at tolerating low temperatures. The metabolic production rates linked to the performance of physical activity [35], and the improved options for adaptation to low temperatures with increasingly lighter and more comfortable clothes must also be taken into account. Verbos et al. [101] argued that the use of technology in clothing (technology-based adaptation strategies) could extend human capacity to accept previously intolerable conditions.

The particular preferences of this tourist niche, hikers, are also reflected in their favourite season of the year for hiking. Most of those interviewed chose the spring while a considerably smaller group chose the autumn.

As regards possible limitations of this research, in addition to those mentioned above linked to the sample size, the procedure used to assess climate preferences is perhaps open to question. Respondents answered the questionnaire ex situ (responding to what might be called hypothetical scenarios). Some authors argue that the ideal option is to analyse the preferences declared in situ by respondents assessing real scenarios [40], i.e., to ask them about their perception of the atmospheric environment at the place where they are hiking (conducting simultaneous questionnaire surveys and weather measurements, so as to gauge "tourists' responses to meteorological conditions") [101]. Studies of this type have been conducted, for example, by Oliveira and Andrade [102] Andrade et al. [103] and Rutty and Scott [77]. Despite the fact that these previous authors took a different approach, the validity of the ex-situ online questionnaire applied here is confirmed by its frequent use in tourism climatology, as cited in the background and data section.

In future research we intend to analyse the particularities of the climate for hiking according to geographic and sociocultural specificities and we will also be assessing the climate potential for hiking tourism in different Spanish mountain areas. This will provide a new weather-types method for assessing the suitability of these areas for hiking from the climatic point of view. In addition, it will provide new information for climate-tourism research regarding users' perceptions of different aspects of the climate and their suitability for hiking. These results could also be useful for the tourism industry and for tourists, to the extent that they could help them organize and schedule their holidays in line with their preferences. This could be facilitated by presenting climate data regarding suitability for hiking tourism in calendar form.

Author Contributions: The questionnaires were drawn up and statistically analysed by M.B.G.-M., X.A.A.-L. and R.P.-M. The Introduction and Conclusion were written by X.A.A.-L. and R.P.-M., while E.M.-I. wrote the Background, Results and Conclusion sections. M.B.G.-M. reviewed the manuscript.

Funding: This research has been conducted within the framework of the $\mathrm{R}+\mathrm{D}+\mathrm{i}$ project with reference number CSO2017-88935-R (funded as part of the Spanish National R\&D\&I Plan of the Spanish Ministerio de Economía y Competitividad) and with the support of the research groups 2017 SGR 25 (Grup de Recerca Consolidat Territori, Turisme, Canvi Climàtic) and SEJ170 (Paisaje, Planificación Territorial y Desarrollo Local).

Conflicts of Interest: The authors declare no conflict of interest.

\section{References}

1. Spinney, J.E.L.; Millward, H. Weather impacts on leisure activities in Halifax, Nova Scotia. Int. J. Biometeorol. 2010, 55, 133-145. [CrossRef] [PubMed]

2. Pate, R.R. Physical activity and public health. A recommendation from the Centers for Disease Control and Prevention and the American College of Sports Medicine. JAMA 1995, 273, 402-407. [CrossRef] [PubMed]

3. Warburton, D.E.; Nicol, C.W.; Bredin, S.S. Health benefits of physical activity: The evidence. Can. Med. Assoc. J. 2006, 174, 801-809. [CrossRef] [PubMed]

4. Thomson-Coon, J.; Boddy, K.; Stein, K.; Whear, R.; Barton, J.; Depledge, M.H. Does participating in physical activity in outdour natural environments have a greater effect on physical and mental wellbeing than physical activity indoors? A systematic review. Environ. Sci. Technol. 2011, 45, 1761-1772. [CrossRef] [PubMed] 
5. Audrey Coetzee, B. Self-Reported Fitness Levels, Actual Fitness Levels and Recorded Energy Expenditure on Graded Hiking Trails. Ph.D. Thesis, University of the Free State, Bloemfontein, South Africa, 2018.

6. Wagner, A.L.; Keusch, F.; Yan, T.; Clarke, P.J. The impact of weather on summer and winter exercise behaviors. J. Sport Health Sci. 2019, 8, 39-45. [CrossRef] [PubMed]

7. Tucker, P.; Gilliland, J. The effect of season and weather on physical activity: A systematic review. Public Health 2007, 121, 909-922. [CrossRef]

8. Moschny, A.; Platen, P.; Klaaßen-Mielke, R.; Trampisch, U.; Hinrichs, T. Physical activity patterns in older men and women in Germany: A cross-sectional study. BMC Public Health 2011, 11, 559. [CrossRef]

9. Witham, M.D.; Donnan, P.T.; Vadiveloo, T.; Sniehotta, F.F.; Crombie, I.K.; Feng, Z.; McMurdo, M.E.T. Association of Day Length and Weather Conditions with Physical Activity Levels in Older Community Dwelling People. PLoS ONE 2014, 9, e85331. [CrossRef]

10. Chan, C.B.; Ryan, D.A. Assessing the Effects of Weather Conditions on Physical Activity Participation Using Objective Measures. Int. J. Environ. Res. Public Health 2009, 6, 2639-2654. [CrossRef]

11. Brocherie, F.; Girard, O.; Millet, G. Emerging environmental and weather challenges in outdour sports. Climate 2015, 3, 492-521. [CrossRef]

12. Baranowski, T.; Thompson, W.O.; DuRant, R.H.; Baranowski, J.; Puhl, J. Observations on physical activity in physical locations: Age, gender, ethnicity and month effects. Res. Q. Exerc. Sport 2005, 29, 371-381. [CrossRef] [PubMed]

13. King, A.C.; Castro, C.; Wilcox, S.; Eyler, A.A.; Sallis, J.F.; Brownson, R.C. Personal and environmental factors associated with physical inactivity among different racial-ethnic groups of US middleaged and older-aged women. Health Psychol. 2000, 19, 354-364. [CrossRef] [PubMed]

14. Wilcox, S.; Castro, C.; King, A.C.; Housemann, R.; Brownson, R.C. Determinants of leisure time physical activity in rural compared with urban older ad ethnically diverse women in the United States. J. Epidemiol. Community Health 2000, 54, 667-672. [CrossRef] [PubMed]

15. Currie, J.L.; Develin, E. Stroll your way to well-being: A survey of the perceived benefits, barriers, community support and stigma associated with pram walking groups designed for new mothers, Sydney, Australia. Health Care Women Int. 2002, 23, 882-893. [CrossRef]

16. Lera, I.; Pérez, T.; Guerrero, C.; Eguíluz, V.M.; Juiz, C. Analysing human mobility patterns of hiking activities through complex network theory. PLoS ONE 2017, 12, e0177712. [CrossRef]

17. Douglas, N.; Derrett, R. Special Interest Tourism; John Wiley and Sons Australia, Ltd.: Milton, Australia, $2001 ;$ p. 475.

18. Chhetri, P.; Arrowsmith, C.; Jackson, M. Determining hiking experiences in nature-based tourist destinations. Tour. Manag. 2004, 25, 31-43. [CrossRef]

19. Pomfret, G. Mountaineering adventure tourists: A conceptual framework for research. Tour. Manag. 2006, 27, 113-123. [CrossRef]

20. Fredman, P.; Tyrvaïnen, L. Frontiers in nature-based tourism. Scand. J. Hosp. Tour. 2010, 10, 177-189. [CrossRef]

21. Gómez-Martín, B. Hiking Tourism in Spain: Origins, Issues and Transformations. Sustainability 2019, 11, 3619. [CrossRef]

22. Breejen, L.D. The experiences of long distance walking: A case study of the West Highland Way in Scotland. Tour. Manag. 2007, 28, 1417-1427. [CrossRef]

23. Smith, M.; Puczko, L. Health, Tourism and Hospitality: Spas, Wellness and Medical Travel, 2nd ed.; Routledge: London, UK, 2014; p. 544.

24. Bowler, D.E.; Buyung-Ali, L.M.; Knight, T.M.; Pullin, A.S. A systematic review of evidence for the added benefits to health of exposure to natural environments. BMC Public Health 2010, 10, 456. [CrossRef]

25. Vicente-Serrano, S.; Rodríguez-Camino, E.; Domínguez-Castro, F.; Azorín-Molina, C.; El Kenawy, A. An updated review on recent trends in observational surface atmospheric variables and their extremes over Spain. Geogr. Res. Lett. 2017, 43, 209-232. [CrossRef]

26. Tourespaña. Turismo de montaña; Instituto de Turismo de España: Madrid, Spain, 2009; p. 200.

27. Sánchez-Sanz, V. El Fenómeno Senderista en España. Análisis por un Panel de Expertos. Ph.D. Thesis, Universidad de Valencia, Valencia, Spain, 2014.

28. Ibarra, E.M.; Martínez, R.P. Preferencias Climáticas para la Práctica del Senderismo en España: Resultados Preliminaries. Investig. Tur. 2017, 13, 164-177.

29. George, D. Weather and mountain activities. Weather 1993, 48, 404-410. [CrossRef] 
30. Scott, D.; Jones, B.; Konopek, J. Implications of climate and environmental change for nature-based tourism in the Canadian Rocky Mountains: A case study of Waterton Lakes National Park. Tour. Manag. 2008, 28, 570-579. [CrossRef]

31. Dubois, G.; Ceron, J.P.; van de Walle, I.; Picard, R.; CREDOC. Climat, Meteorology et Frequentation Touristique, Rapport Final; Ministere de l'Ecologie, de l'Energie, du Développement Durable et de la Mer: Paris, France, 2009; p. 101.

32. Jänicke, L.; Abegg, B.; Steiger, R. Wheather preferences of summer tourists in mountain environments: A case study in the Bavarian Alps, Germany. In Proceedings of the 4th International Conference on Climate, Tourism and Recreation (CCTR), Istambul, Turkey, 17-19 September 2015; The Commission on Climate, Tourism and Recreation (CCTR) of the International Society of Biometeorology (ISB): Istambul, Turkey, 2015; pp. 63-67.

33. Dubois, G.; Ceron, J.P.; Gossling, S.; Hall, C.M. Weather preferences of French tourists: Lessons for climate change impact assessment. Clim. Chang. 2016, 136, 339-351. [CrossRef]

34. Gómez-Martín, M.B. Clima y Turismo en Cataluña: Evaluación del Potencial Climático-Turístico de la Estación Estival. Ph.D. Thesis, Universidad de Barcelona, Barcelona, Spain, 2000.

35. Martínez-Ibarra, E. Consideraciones Geográficas en Torno al Binomio Clima-Turismo: Aplicación al Litoral Alicantino. Ph.D. Thesis, Universidad de Alicante, Alicante, Spain, 2006.

36. Li, C.H.; Lin, S.H. Influence of weather conditions on hiking behavior. Int. J. Biometeorol. 2012, 56, 777-781. [CrossRef]

37. UNWTO. UNWTO Annual Report 2018; UNWTO: Madrid, Spain, 2008; p. 20.

38. Gómez-Martín, M.B. Weather, climate and tourism a geographical perspective. Ann. Tour. Res. 2005, 3, 571-591. [CrossRef]

39. De Freitas, C.R. Recent developments in Tourism Climatology. In Yies Conference Report, Tourism and Climate, Japan, September 27, 2009; Yamanashi Institute of Environmental Sciences: Yamanashi, Japan, 2009; pp. 1-22.

40. Besancenot, J.P. Climat et Tourisme; Masson: Paris, France, 1990; p. 223.

41. De Freitas, C.R. Recreation climate assessment. Int. J. Climatol. 1990, 10, 89-103. [CrossRef]

42. De Freitas, C.R. Tourism climatology: Evaluating environmental information for decision making and business planning in the recreation and tourism sector. Int. J. Biometeorol. 2003, 48, 45-54. [CrossRef]

43. Martínez-Ibarra, E.; Gómez-Martín, M.B. Progress in Tourism Climatology. In Tourism and Developments: Issues and Challenges; Mihalic, T., Gartner, W.C., Eds.; Nova Science Publishers: New York, NY, USA, 2012; pp. 121-138.

44. Gómez-Martín, M.B.; Armesto-López, X.A.; Martínez-Ibarra, E. Tourists, Weather and Climate. Official Tourism Promotion Websites as a Source of Information. Atmosphere 2017, 8, 255. [CrossRef]

45. Elsasser, H.; Bürki, R. Climate change as a threat to tourism in the Alps. Clim. Res. 2002, 20, 253-257. [CrossRef]

46. Smith, K. The influence of weather and climate on recreation and tourism. Weather 1993, 48, 398-404. [CrossRef]

47. Coghlan, A.; Prideaux, B. Welcome to the Wet Tropics: The importance of weather in reef tourism resilience. Curr. Issues Tour. 2009, 12, 89-104. [CrossRef]

48. Becken, S.; Wilson, J. The impacts of weather on tourist travel. Tour. Geogr. 2013, 15, 620-639. [CrossRef]

49. Jeuring, J.H.G. Weather perceptions, holiday satisfaction and perceived attractiveness of domestic vacationing in The Netherlands. Tour. Manag. 2017, 61, 70-81. [CrossRef]

50. Nicholls, S.; Holecek, D.F.; Noh, J. Impact of weather variability on golfing activity and implications of climate change. Tour. Anal. 2008, 13, 117-130. [CrossRef]

51. Shih, C.; Nicholls, S.; Holecek, D.F. Impact of Weather on Downhill Ski Lift Ticket Sales. J. Travel Res. 2009, 47, 359-372. [CrossRef]

52. Becken, S. Measuring the Effect of Weather on Tourism: A Destination and Activity-Based Analysis. J. Travel Res. 2012, 52, 156-167. [CrossRef]

53. Gómez-Martín, M.; Martínez-Ibarra, E. Tourism demand and atmospheric parameters: Non-intrusive observation techniques. Clim. Res. 2012, 51, 135-145. [CrossRef]

54. De Freitas, C.R. Weather and place-based human behaviour. Int. J. Biometeorol. 2015, 59, 55-63. [CrossRef] [PubMed]

55. Scott, D.; Lemieux, C. Weather and Climate Information for Tourism. Procedia Environ. Sci. 2010, 1, $146-183$. [CrossRef] 
56. Becken, S.; Wilson, J.; Hughey, K. Planning for Climate, Weather and Other Natural Disasters-Tourism in Northland; LEaP Research Paper; Lincoln University: Lincoln, New Zealand, 2011.

57. Gómez-Martín, M.B.; Armesto-López, X.A.; Martínez-Ibarra, E. The Spanish tourist sector facing extreme climate events: A case study of domestic tourism in the heat wave of 2003. Int. J. Biometeorol. 2014, 58,781-797. [CrossRef] [PubMed]

58. Martínez-Ibarra, E. Análisis geográfico de inundaciones relámpago en espacios turísticos de norte de la provincia de Alicante. Pap. Geogr. 2017, 65-81. [CrossRef]

59. Smith, K. The effect of weather conditions on the public demand for meteorological information. J. Clim. 1981, 1, 381-393. [CrossRef]

60. Becken, S.; Wilson, J.; Reisinger, A. Weather, Climate and Tourism: A New Zealand Perspective; Land Environment and People-Technical Report; Lincoln University: Lincoln, New Zealand, 2010.

61. Bansal, H.; Eiselt, H. Exploratory research of tourist motivations and planning. Tour. Manag. 2004, 25, 387-396. [CrossRef]

62. Hamilton, J.M.; Lau, M.A. The Role of Climate Information in Tourist Destination Choice Decision-making. In Tourism and Global Environmental Change; Gossling, S., Hall, C.M., Eds.; Routledge: London, UK, 2005; p. 22.

63. Eugenio-Martin, J.L.; Campos-Soria, J.A. Climate in the region of origin and destination choice in outbound tourism demand. Tour. Manag. 2010, 31, 744-753. [CrossRef]

64. Cools, M.; Moons, E.; Creemers, L.; Wets, G. Changes in Travel Behavior in Response to Weather Conditions: Do Type of Weather and Trip Purpose Matter? Transport. Res. Rec. 2010, 2157, 22-28. [CrossRef]

65. Rossello-Nadal, J.; Antoni Riera-Font, A.; Cardenas, V. The Impact of Weather Variability on British Outbound Flows. Clim. Chang. 2011, 105, 281-292. [CrossRef]

66. Charalampopoulos, I.; Nastos, P.T.; Didaskalou, E. Human Thermal Conditions and North Europeans' Web Searching Behavior (Google Trends) on Mediterranean Touristic Destinations. Urban Sci. 2017, 1, 8. [CrossRef]

67. Koetse, M.J.; Rietveld, R. The impact of climate change and weather on transport: An overview of research findings. Transp. Res. Part D 2009, 14, 205-221. [CrossRef]

68. Martínez-Ibarra, E. Climate, water and tourism: Causes and effects of droughts associated with urban development and tourism in Benidorm (Spain). Int. J. Biometeorol. 2015, 59, 487-501. [CrossRef] [PubMed]

69. Gössling, S.; Abegg, B.; Steiger, R. "It Was Raining All the Time!": Ex Post Tourist Weather Perceptions. Atmosphere 2016, 7, 10. [CrossRef]

70. Besancenot, J.P.; Mounier, J.; de Lavenne, F. Les conditions climatiques du tourisme littoral: Une méthode de recherche comprénshive. Noris 1978, 99, 357-382.

71. Mieczkowski, Z. The Tourism Climatic Index: A Method of Evaluating World Climates for Tourism. Can. Geogr. Geogr. Can. 1985, 29, 220-233. [CrossRef]

72. Yu, G.; Schwartz, Z.; Walsh, J.E. A weather-resolving index for assessing the impact of climate change on tourism related climate resources. Clim. Chang. 2009, 95, 551-573. [CrossRef]

73. Martínez-Ibarra, E. The use of webcam images to determine tourist-climate aptitude: Favorable weather types for sun and beach tourism on the Alicante coast (Spain). Int. J. Biometeorol. 2011, 55, 373-385. [CrossRef]

74. Morgan, R.; Gatell, E.; Junyent, R.; Micallef, A.; Özhan, E.; Williams, A.T. An improved user-based beach climate index. J. Coast. Conserv. 2000, 6, 41-50. [CrossRef]

75. De Freitas, C.R.; Scott, D.; McBoyle, G. A second generation climate index for tourism (CIT): Specification and verification. Int. J. Biometeorol. 2008, 52, 399-407. [CrossRef]

76. Rutty, M.; Scott, D. Will the Mediterranean Become “Too Hot" for Tourism? A Reassessment. Tour. Hosp. Plan. Dev. 2010, 7, 267-281. [CrossRef]

77. Rutty, M.; Scott, D. Bioclimatic comfort and the thermal perceptions and preferences of beach tourists. Int. J. Biometeorol. 2015, 37, 37-45. [CrossRef] [PubMed]

78. Moreno, A. Mediterranean Tourism and Climate (Change): A Survey-Based Study. Tour. Hosp. Plan. Dev. 2010, 7, 253-265. [CrossRef]

79. Georgopoulou, E.; Mirasgedis, S.; Sarafidis, Y.; Hontou, V.; Gakis, N.; Lalas, D.P. Climatic preferences for beach tourism: An empirical study on Greek islands. Theor. Appl. Clim. 2018, 137, 667-691. [CrossRef]

80. Gómez-Martín, M. Climate potential and tourist demand in Catalonia (Spain) during the summer season. Clim. Res. 2006, 32, 75-87. [CrossRef] 
81. Fernandes, A.S. Relaçao Clima-Turismo: Um Contributo para o Planjejamento de Destinos Turisticos. Master's Thesis, Universidade de Brasília, Brasilia, Brazil, 2017.

82. Guo, P. Weather and Air Quality Preferences of Urban Tourists in China. Bachelor's Thesis, University of Waterloo, Waterloo, ON, Canada, 2015.

83. Winslow, C.E.A.; Herrington, L.P. Subjective reactions of human beings to certain outdoor atmospheric conditions. Heating-Piping-Air Cond. J. 1935, 7, 551-556.

84. Auliciems, A. Weather Perception-A Subtropical Winter Study. Weather 1976, 31, 312-316. [CrossRef]

85. Auliciems, A. Mood dependency on low intensity atmospheric variability. Int. J. Biometeorol. 1978, 22, $20-32$. [CrossRef]

86. Barbière, E.B. O fator climatico nos sistemas territoriais de recreação. Rev. Bras. Geogr. 1981, 2, $145-265$.

87. Maddison, D. In Search of Warmer Climates? The Impact of Climate Change on Flows of British Tourists. Clim. Chang. 2001, 49, 193-208. [CrossRef]

88. Batista Tamayo, L.M.; Matos Pupo, F. La aptitud climática del destino turístico Jardines del Rey (Cuba). Los tipos de tiempo. In El Clima Entre el Mar y la Montaña; García-Codrón, J.C., Diego-Liaño, C., Fernández-de-Arróyabe-Hernáez, P., Garmendia-Pedraza, C., Rasilla-Álvarez, D., Eds.; Serie B; Asociación Española de Climatología: Santander, Spain, 2004; pp. 561-570.

89. Scott, D.; Gossling, S.; de Freitas, C. Preferred climates for tourism: Case studies from Canada, New Zealand and Sweden. Clim. Res. 2008, 45, 61-73. [CrossRef]

90. Rutty, M.; Scott, D. Comparison of Climate Preferences for Domestic and International Beach Holidays: A Case Study of Canadian Travelers. Atmosphere 2016, 7, 30. [CrossRef]

91. Crowe, R.; McKay, G.; Baker, W. The Tourist and Outdoor Recreation Climate of Ontario, Volume I: Objectives and Definitions of Seasons; Project Report No. REC-1-73; Environment Canada, Atmospheric Environment Service: Downsview, ON, Canada, 1973.

92. Steiger, R.; Abegg, B.; Jänicke, L. Rain, rain, go away, come again another day. Weather preferences of summer tourists in mountain enviroments. Atmosphere 2016, 7, 63. [CrossRef]

93. Jeuring, J.H.G.; Peters, K.B.M. The influence of the weather on tourist experiences: Analysing travel blog narratives. J. Vacat. Mark. 2013, 19, 209-219. [CrossRef]

94. Llorente-Martínez, F. Meteorología (VII): La Visibilidad y los Factores Meteorológicos que Influyen en ella. RAM: 2003. Available online: https://www.tiempo.com/ram/1041/meteorologa-viila-visibilidad-y-losfactores-meteorolgicos-que-influyen-en-ella/ (accessed on 24 October 2019).

95. Gómez-Martín, M.B. Percepción de la demanda y métodos de evaluación de la potencialidad turística de los recursos atmosféricos en Cataluña. Doc. D'anàlisi Geogr. 2004, 44, 43-70.

96. Martínez-Ibarra, E. Tipos de tiempo para el turismo de sol y playa en el litoral alicantino. Estud. Geogr. 2008, 69, 135-155.

97. Martínez-Ibarra, E. Evaluación de la aptitud climático-turística para el turismo de sol y playa en Alicante (1974-2003). Investig. Geogr. 2008, 45, 141-162. [CrossRef]

98. Scott, D.; Rutty, M.; Amelung, B.; Tang, M. An Inter-Comparison of the Holiday Climate Index (HCI) and the Tourism Climate Index (TCI) in Europe. Atmosphere 2016, 7, 80. [CrossRef]

99. Li, C. The aceptable level of weather condition among the different types of hikers. J. Phys. Educ. High Educ. 2008, 10, 43-54.

100. Çalışkan, O.; Çiçek, I.; Matzarakis, A. The climate and bioclimate of Bursa (Turkey) from the perspective of tourism. Theor. Appl. Climatol. 2012, 107, 417-425. [CrossRef]

101. Verbos, R.I.; Altschuler, B.; Brownlee, M.T.J. Weather Studies in Outdoor Recreation and Nature-Based Tourism: A Research Synthesis and Gap Analysis. Leis. Sci. 2017, 1-24. [CrossRef]

102. Oliveira, S.; Andrade, H. An initial assessment of the bioclimatic comfort in an outdoor public space in Lisbon. Int. J. Biometeorol. 2007, 52, 69-84. [CrossRef] [PubMed]

103. Andrade, H.; Alcoforado, M.J.; Oliveira, S. Perception of temperature and wind by users of public outdoor spaces: Relationsships with weather parameters and personal characteristics. Int. J. Biometeorol. 2011, 55, 665-680. [CrossRef] [PubMed]

(C) 2019 by the authors. Licensee MDPI, Basel, Switzerland. This article is an open access article distributed under the terms and conditions of the Creative Commons Attribution (CC BY) license (http://creativecommons.org/licenses/by/4.0/). 